\title{
Planning and urban regeneration since 2010: a recipe for conflict and dispute?
}

\author{
Barry Goodchild and Catherine Hammond* \\ Sheffield Hallam University
}

\begin{abstract}
Summary
Both parties to the present Conservative-Liberal Democrat Coalition government came to power in $\mathbf{2 0 1 0}$ with a decentralised, localist policy agenda in planning. In power, the localist agenda has been implemented in part through the establishment of procedures for neighbourhood planning. The benefits of neighbourhood planning look limited, however. Moreover, the main policy priority has been to promote growth and development. That priority has led, in turn, to repeated conflict- with the traditional establishment keen on conservation, with Conservative supporters living in the suburbs and countryside, with local authorities and their national organisations eager to maintain environmental and amenity standards and finally with the supporters of urban regeneration, concerned with the future of areas in decline. Taken together, the range of opposition expresses widespread unease about the implications for social justice and the quality of life.
\end{abstract}

Keywords: planning, localist, neighbourhood, regeneration, growth, development.

\section{Introduction}

The broad policy field of 'town planning' or 'spatial planning', as it is also called, impacts on daily life through determining the extent to which local authorities and local people can control environmental standards and in addition through organising programmes of public investment and urban regeneration. Planning is also about a series of very big national or regional issues- for example: airport capacity for London, high speed rail lines and energy provision (fracking, wind turbines, nuclear power and so on). These big, specific issues are not, however, the focus here. Instead, the focus is on the apparently more mundane planning issues that affect the quality of life in local communities, from the election of a Coalition government in 2010 to the summer of 2013. Responsibility for planning policy is largely devolved to the constituent countries of the United Kingdom. The focus here is on England.

The paper has three main sections. It starts with a consideration of methodology, that is to say the issues involved in the preparation of a coherent analysis. It goes on, in the subsequent two sections, to analyse specific policy themes and conflicts. 


\section{Analysing policy change and implementation}

The standard model of policy change is of a government coming to power, passing a law and then organising a programme of implementation that brings a variety of different actors into line with the policy aims. As is consistent with this standard model, governments are typically judged against their manifesto commitments. For the present Conservative Coalition government, an evaluation of the record since election in 2010 would, therefore, be based on key policy documents prepared in opposition, notably in a series of 'Green Papers' in which commitments were made to promote neighbourhood planning and to abolish the Regional Development Agencies, their associated Regional Spatial Strategies and a national Infrastructure Planning Commission (Conservative Party, 2009a; 2009b; 2010).

Admittedly, after the election, the Conservatives had to negotiate with the Liberal Democrat Party. However, the Liberal Democrat 'Manifesto 2010' said little about town planning or urban regeneration and it also endorsed the principle of handing power to local communities. ${ }^{1}$ As stated, the agreed Coalition Programme (HM Government, 2010a) focussed on the abolition of the Regional Development Agencies and the national Infrastructure Commission, these being quickly achieved and on other, slightly longer term initiatives to simplify planning guidance and promote neighbourhood planning.

Yet neither the manifesto commitments nor the agreed Coalition Document provides a fully adequate basis for interpreting Coalition policy. The Coalition government came to power at a time of economic crisis and faced a major public sector budget shortfall, the full implications of which no party had previously wished to publicise to the electorate. The shortfall, in turn, has posed a dilemma between austerity and the promotion of growth and has provided a constraining background to virtually all policy statements and actions.

In addition, the Coalition Document is intended to promote a sense of agreement and consistency. It glosses over differences of emphasis, not so much in the case of planning between the Liberal Democrats, and the Conservatives but differences that cut across all the parties and are about how the planning system is to be used. The Coalition Document (HM Government, 2010: 18) states, for example 'We will create a presumption in favour of sustainable development in the planning system' without, however, defining the meaning of sustainable development. As was later recognised (CLG, 2012), the concept has environmental, social and economic aspects and the balance between these different aspects is variable. A presumption in favour of sustainable development does not mean, in any case, that all development is presumed sustainable. As applied to specific sites, sustainable development may mean no development (see While, this issue).

The combination of manifesto commitments, a bleak economic context and conflicting interpretations has prevented the implementation of a single consistent, coherent policy. The Coalition government has instead sought to weave together varied and sometimes contradictory policy aims and themes and has, on occasion, produced policy statements that, in the words of the government's critics, look thin, lack narrative and lack clarity (House of Commons, 2011: 7-8). A desire to simplify and reduce the length of policy guidance in planning, from over 1,000 to around 50 pages has contributed to this impression of imprecision. ${ }^{2}$ The revised National Planning Policy Framework (NPPF) (CLG, 2012) has to cope with a series of complex technical issues, whilst simultaneously seeking to reflect the political priorities of the government. National policy statements have also had to cope with significant, growing regional variations in the property market, without the possibility of varied regional plans as might have been possible before the abolition of the Regional Spatial Strategies. 
In this context, a series of specific themes, to be more accurate two pairs of opposing policy aims and themes are apparent in national policy. The Coalition government has sought to combine austerity with economic growth and, in addition, partial deregulation with neighbourhood planning.

\section{Between growth and austerity}

The term 'austerity urbanism' has been coined by Peck (2012) as a means of summarising and understanding urban policy in a context of extreme public expenditure cuts and in the US municipal bankruptcies. The latter is not an issue in the UK, where local government is largely financed by transfers from the central government and where local expenditure is as a result subject to strict central controls. Cuts have, nevertheless, been very large indeed. For example, according to the Institute for Financial Affairs (Crawford and Phillips, 2012), local authority budgets for 2011-12 (halfway through the current programme of cuts) have implied real-terms cuts in net current service expenditure (excluding education) of 9.4 per cent since 2009-10, or 10.4 per cent when expenditure on fire and police services is also excluded. Further, expenditure on 'planning and development services' has been particularly badly hit, with an average cut across England of 43 per cent over the two years since 2009-10. As is implicit in these figures, expenditure cuts have varied from service to service. Core services such as education and the personal social services have been protected. Planning, expenditure on which is mostly about personnel, and services such as community development and local infrastructure investment have suffered instead.

The abolition of the Regional Development Agencies and a decline in other centrally funded investment strategies have had the same effect for programmes funded by central government. An estimate made on behalf of a Select Committee of the House of Commons (2011: 16) is that "annual spending on "core" regeneration programmes (excluding the additional cross-spending review streams such as rail and Olympic investment)' experienced a '65\% reduction over the two years' from 2009/10 onwards. As the House of Commons report also noted, as the urban regeneration programmes were mostly targeted on the less prosperous cities of the Midlands and the North of England, the cuts also have had regional implications and meant a shift in priorities towards the South East. Other related policy changes, the abandonment of the Housing Market Renewal programme, the introduction of a New Homes Bonus to be paid to local authorities for every house built in their area- has had the same effect in diverting funds away from areas in decline.

Against this background, the Coalition government has repeatedly referred to local growth as a central aim, both in relation to planning and urban regeneration. The titles of official policy documents illustrate the point, for example 'Local growth: realising every place's potential' (HM Government, 2010b) or 'Regeneration to enable growth' (CLG, 2011). In addition, these documents have seen the reform of the planning system as a prerequisite for achieving growth. The Local Growth White Paper (HM Government, 2010b: 7) states, for example:

'A further feature of earlier approaches was the belief that planning could both determine where growth should happen and stimulate that growth. This approach failed as it went against the grain of markets. Regional and other strategies stifled natural and healthy competition between places and inhibited growth as a consequence.' 
For the critics, however, and this includes the advocates of urban regeneration, the reform of the planning system was largely irrelevant to the promotion of growth. The Select Committee (House of Commons, 2011: 20-21) states, for example:

'The Government may have good reasons for its proposed reforms to the planning system, but it is not clear that they will have a significant bearing upon regeneration...Planning has in fact brought significant benefits to regeneration, in terms of co-ordination, community involvement and town centre preservation.'

The Select Committee went on to cite evidence that the cuts in expenditure had come at exactly the wrong time, when many development projects had stalled for want of finance and that in addition the abolition of the Regional Development Agencies was likely to lead to a loss of institutional and staffing expertise of a type that was not likely to be replaced or replicated.

The government and the Select Committee were at cross purposes. Despite some confusion in government documents, the main thrust of the Coalition strategy is not towards urban regeneration as it is conventionally defined as the reversal of decline at either the level of neighbourhoods or cities. It is about promoting investments in places already subject to growth or subject to development pressures in the past few years and persuading local communities in those places to accept development proposals. The New Homes Bonus is part of this strategy to provide incentives to local authorities to accept growth. Another, more local incentive concerns the destination of development charges: so-called Section 106 agreements (a negotiated charge) and the Community Infrastructure Levy (CIL) (a standardised charge) that, since coming into force in 2010, runs alongside as a partial replacement to Section 106 agreements. A change to the CIL regulations in April 2013 is intended to provide incentives at a very local level. Henceforth, 15 per cent of the $\mathrm{CIL}$ revenue will go directly to Parish and Town Councils in England and Community Councils in Wales "to help communities accommodate the impacts of new development and strengthen the role and financial autonomy of neighbourhoods" (CLG, April 2013: 23). Where there is a neighbourhood plan in place this is increased to 25 per cent.

The shift in spending from urban regeneration projects in the Midlands and North of England to the South East was therefore an intentional aspect of policy. The Local Growth White Paper, for example, endorsed the 'agglomeration economics' of London and suggested that 'such agglomeration effects may also help drive further growth in other areas', (HM Government, 2010b: 7) presumably through the growth of particular towns and cities and through transport investments that would help enlarge local labour and property markets.

At the same time, for all the emphasis on growth, austerity is never far away in the policies of the Coalition government. The promotion of house building has been a particular policy aim. The preceding Labour governments also sought to promote house building and, during the boom years from 2000 to 2008 , were able to do so merely by ensuring the availability of sufficient sites. Such was the aim of the Regional Spatial Strategies that were abandoned once the Coalition government came to power. The house building industry still argued, however, that insufficient sites were made available. Since 2008 , in contrast, the house building industry have been so depressed that land availability for new housing has become more of a long-term concern, of policy interest but no longer an effective constraint on to house building. Instead, both the house building pressure groups (HBF, 2011) and the government have turned their attention to the financial viability of proposals and have sought in particular, to reduce any regulatory measures that increase development costs. 
For example, the National Planning Policy Framework (CLG, 2012: 41) has instructed local authorities:

'To ensure viability, the costs of any requirements likely to be applied to development, such as requirements for affordable housing, standards, infrastructure contributions or other requirements should, when taking account of the normal cost of development and mitigation, provide competitive returns to a willing land owner and willing developer to enable the development to be deliverable.'

As was later explained in the Reports of the Housing Delivery Group (2012a; 2012b) viability is to be balanced against building and housing standards, and as part of this, balanced against the standards that promote environmental sustainability. If a proposal is not viable, standards should be reduced or another, probably greenfield site used with lower development costs. In addition, as permitted under the Growth and Infrastructure Act 2013, developers may renegotiate previously agreed section 106 commitments relating to affordable housing provision if these are seen to be undermining development viability. Renegotiation of planning agreements, thereby reducing private support for affordable housing has not been balanced, however, by increased public investment and, in any case, goes against the other strand of policy, to compensate and find incentives for communities experiencing development.

\section{Between deregulation and neighbourhood planning}

Policies for urban growth and development invariably become caught between the conflicting pressures of the market and property interests on one hand and local communities on the other. The conflict is almost certainly structural in a densely occupied country such as England, where urban development pressures create patterns of winners and losers. The opposition of local communities to new housing was, for example, a reason for the introduction of the former system of Regional Spatial Strategies. The conflict is, nevertheless, most obvious in Conservative Party policies partly owing to the type of area in which their support is concentrated and partly because of centrality of both local democracy and deregulation in the party discourse (Goodchild, 2010). In power, the conflict has generated successive rounds of controversy.

The initial occasion for conflict was the attempt to simplify the national planning guidelines in the form of a revised National Planning Policy Framework (NPPF). For conservationist pressure groups such as the National Trust and the Campaign for the Protection of Rural England simplification amounted to deregulation and was likely to undermine policies to protect greenfield sites and rural landscapes. Likewise, for local authorities simplification risked undermining their ability to control development and would therefore also undermine the government's commitment to localism. Opposition to deregulation was explicitly supported by The Daily Telegraph, otherwise a staunch supporter of the Conservatives. Under the general title of 'Hands off our land', The Daily Telegraph repeatedly presented the planning reforms as going against the wishes of Conservative supporters living in rural and suburban areas- the so-called 'middle England.'

The simplified guidelines were eventually modified in a way that recognised a preference for brownfield rather than greenfield development and so went some way to satisfy the conservationist opponents. The NPPF (CLG, 2012), as revised, is not a crude deregulatory document. In particular, guidance reiterates the importance of local policy 
being led by an up-to-date local plan. Like government policy in general the NPPF carries mixed messages.

However there are caveats. The NPPF (op cit, 4) states baldly that 'local planning authorities should positively seek opportunities to meet the development needs of their area', without balancing need against environmental capacity and without taking into account the actual expected rate of house building. In depressed areas, especially in the North of England, assessments of the need for housing, for example, are likely to result in a gross overestimate of land release in comparison to the likely rate of house building. In addition, the document goes to state that "where the development plan remains absent, silent or relevant policies are out of date 'permission for development should be granted unless it contravenes policy in the NPPF or it can be demonstrated that the harm would outweigh the benefits' (ibid). Local planning authorities had 12 months to prepare and approve a development framework core strategy in conformity with the NPPF, but on 27th March 2013 when this period expired only seven per cent of local authorities had a compliant core strategy, and only 48 per cent an adopted core strategy (Planning, 25th March, 2013). This has led, in turn, to outcries in the press and from local authorities of threats of large scale, unplanned development on greenfield land (LGiU, 2013).

Moreover, the guidelines have been introduced in a context where other initiatives have explicitly promoted aspects of the ability of the planning system to control development. The object of change has been an apparently obscure and legalistic issue- the scope of permitted development rights as defined under the Town and Country Planning (General Permitted Development) (Amendment) (England) Order. The general development order defines cases where development is granted automatically, with no need to apply for permission. Changes to permitted development can therefore either relax or tighten local planning control.

As modified in 2013 , developers no longer need to apply for planning permission for change of use from office to residential development, subject to a prior determination on whether approval is required in relation to contamination or flooding risks, or transport and highways impacts. Removing the need for planning permission in such cases also circumvents the imposition of planning conditions such as affordable homes provision. The strength of opposition from local planning authorities was seen in the submission of 155 applications for exemption, only seven of which were successful ('Planning', 14 July 2013). The main concern has been that, in areas of high house prices, developers would target occupied rather than unoccupied offices and that, as a result, employment generating activities would be lost. Brighton and Hove Council has attempted to use another procedure, an article four direction to protect sources of employment, but it is unclear whether central government will allow this.

For a period of three years from May 2013, permitted development rights have also been extended for homeowners and business located in non-protected areas. The modifications include allowance for a doubling in the size of single story extension to $8 \mathrm{~m}$ for detached houses and $6 \mathrm{~m}$ for all other houses and increasing the size of extensions to shops, professional and financial services and offices to $100 \mathrm{~m} 2$. The proposals were opposed by the Royal Town Planning Institute ${ }^{3}$ and the Local Government Association ${ }^{4}$ and generated sufficient political opposition for the House of Lords to pass an amendment that local authorities be allowed to opt out. This was only narrowly defeated in the House of Commons, and resulted in the introduction of a neighbour consultation scheme that is intended to provide a 'light touch' procedure.

The other, democratic and localist aspect of Coalition policy has proceeded almost without controversy, but also without reference to the deregulatory measures that limit community control. As introduced under the Localism Act (2011), neighbourhoods can 
establish a Neighbourhood Forum, who then takes responsibility for preparing a plan in conformity with national policy and the Local Plan. Once the plan is complete it undergoes an independent examination. Once the plan is confirmed to meet its statutory requirements it goes to a neighbourhood referendum and a 50 per cent vote is required for the plan to take legal force (Locality, 2012). The effect is to produce a very local tier of plans alongside the District-wide core strategies and plans produced by local authorities.

A report by the Local Government Information Unit (LGiU, 2013: 4-5) has summarised three concerns about the implementation of neighbourhood planning under current legislation.

First, the powers of Neighbourhood Forums are limited. Neighbourhood Plans cannot include proposals that are contrary to the Local Plan or the National Planning Policy Framework.

Second, not all areas have a Neighbourhood Forum. Parish and Town Councils are able to act as Neighbourhood Forums. Neighbourhood Forums must, however, be established from scratch where these bodies do not exist.

Third, the resources for Neighbourhood Forums are limited. Estimates for the production of a Neighbourhood Plan range from $£ 20,000$ to $£ 100,000$ which, given the low level of funding allocated by government to support Neighbourhood Plans, must in general be found by local communities.

This latter concern regarding the cost was likely to deter plan preparation and to result in patchy plan coverage at best, with most plans prepared in the most prosperous areas. Neighbourhood planning is, in any case, almost irrelevant in depressed areas without development pressures, unless public funds are used to stimulate investment.

\section{Conclusions}

The effects of planning policy are slow to appear, long term in their consequences and difficult to reverse. The policies of the Coalition government are not devoid of vision, even if the vision itself is contentious. The shift in resources to promote growth in London and the South East is, for example, a strategic decision that goes with the grain of recent development trends. The promotion of neighbourhood planning also involves a social vision and goes with the grain of many previous measures that have promoted community involvement, for example in local plan making and in neighbourhood regeneration. In contrast, other aspects of planning- notably the relaxation of controls on home extensions, the removal of controls on office conversions, the increased emphasis on financial viability in local plans- can only be understood as a short-term response to the financial crisis of 2008 onwards. These measures endorse reduced standards in building quality and infrastructure provision and risk institutionalising poor quality development.

The Coalition government came to power promising to simplify the planning system. The government has succeeded in shortening national planning guidance and it is likely, in the future, that it will also codify and consolidate other, more technical sources of guidance. Short government policy documents and consolidated guidance are not necessarily simple documents, however. They still have to be interpreted and applied to varied situations. The promotion of 'sustainable development' is the main aim of planning, as is widely recognised, and this is itself a complex concept, with different aspects- the environmental, social and economic. Simplification without deregulation is 
a mirage and full-scale deregulation is unlikely given the political opposition and the various practical implications that have become evident over the past few years. The Coalition government has, nevertheless, altered the emphasis given to the different aspects of sustainable development, with a greater priority given to development rather than conservation or local amenity.

Recognition of complexity also means recognition that the dominant national policy discourse has omissions and biases. The withdrawal of funding tends to undermine policies for community-based regeneration, targeted on areas in economic decline as The House of Commons (2011) Select Committee has argued. The sheer cost of preparing local plans and the various cuts to local authority staffing have similar implications. It is pointless giving people the right to prepare local plans if no support is available to help them prepare those plans. Finally, as was apparent in relation to opposition to the reformed planning guidance, the conflict between development and amenity is in itself too narrow. The question is not just to decide where and where not to build. The question is also to ensure that new build and new infrastructure is itself sustainable and minimises both short-term, local and long-term environmental impacts.

\section{Notes}

${ }^{1}$ Consulted September 2013 at http://templatelab.com/libdem manifesto 2010/

2 As estimated by government at https://www.gov.uk/government/policies/making-theplanning-system-work-more-efficiently-and-effectively

3 The Royal Town Planning Institute: 'Response to Permitted Development Rights consultation. Response to the Department for Communities and Local Government'. Date: 21/12/12. Consulted at the RTPI website, August 2013 at http://www.rtpi.org.uk/knowledge/consultations/2012-responses/

4 'Proposed changes to permitted development for householder extensions' Briefing note from the Local Government Association 18th September 2012, consulted August 2013 at the Knowledge Hub of the website of the LGA at https://knowledgehub.local.gov.uk/web/khub

* Correspondence Address: Professor Barry Goodchild, Urban and Regional Studies Research, Faculty of Development and Society, Sheffield Hallam University, City Campus, Sheffield, S1 1WB. Email: b.j.goodchild@shu.ac.uk

\section{References}

Communities and Local Government (2011) Regeneration to enable growth; What Government is doing in support of community-led regeneration. London: CLG.

Communities and Local Government (2012) National Planning Policy Framework. London: CLG.

Communities and Local Government (2013) Community Infrastructure Levy Guidance. London: CLG.

Conservative Party (2009a) Control Shift: Returning Power to Local Communities: Responsibility Agenda, Policy Green Paper No.9. The Conservative Party at 30 Millbank, London SW1P 4DP.

Conservative Party (2009b) Strong Foundations: Building Homes and Communities Policy Green Paper No.10, The Conservative Party at 30 Millbank, London SW1P 4DP. 
Conservative Party (2010) Open source Planning Green Paper Policy Green Paper No.14, The Conservative Party at 30 Millbank, London SW1P 4DP.

Crawford, R. and Phillips, D. (2012) Local government spending: where is the axe falling? The Institute for Fiscal Studies Green Budget [online] URL: http://www.ifs.org.uk/publications/6054

Goodchild, B. (2010) Conservative Party policy for planning: caught between the market and local communities. People, Place and Policy, 4, 1, 19-23.

HM Government (2010) The Coalition: our programme for government. London: Cabinet Office.

HM Government (2010b) Local Growth: Realising Every Place's Potential. London: The Stationery Office, CM 7961.

Home Builders Federation (2011) Consultation Response; Reducing the Regulatory Burden [online] URL: http://www.hbf.co.uk/policy-activities/news/view/hbfresponse-to-grant-shapps-letter-of-25-november-2010-reducing-the-regulatoryburden/ (Accessed July 2013)

House of Commons Communities and Local Government Committee (2011) Regeneration Sixth Report of Session 2010-12 Volume I: Report, together with formal minutes, oral and written evidence HC 1014. London: The Stationery Office.

Liberal Democrats (2010) Manifesto 2010, Chris Fox on behalf of the Liberal Democrats, both at 4 Cowley Street, London, SW1P 3NB.

Local Government Information Unit (2013) Localism at risk: is the NPPF delivering land for the people? London: LGiU.

Local Housing Delivery Group (Collective author) (2012a) Viability Testing Local Plans: Advice for planning practitioners. The LHG.

Local Housing Delivery Group (2012b) A Review of Local Standards for the Delivery of New Homes. The LHG.

Locality (2012) Locality Neighbourhood Plans Roadmap Guide. London: Locality.

Peck, J. (2012) Austerity urbanism: American cities under extreme economy. City, 16, 6, 626-55. 